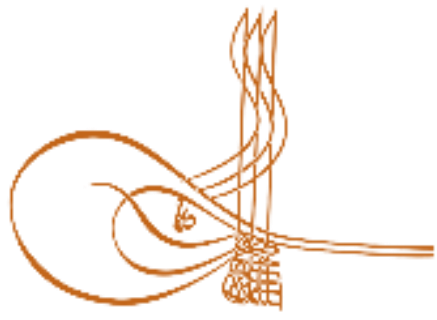

www.turkishstudies.net/social
Turkish Studies - Social Sciences

eISSN: $2667-5617$

Research Article / Araşttrma Makalesi

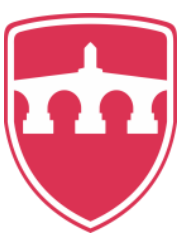

INTERNATIONAL

BALKAN

UNIVERSITY

Sponsored by IBU

\title{
Üniversite Öğrencilerinin Egzersizde Temel Psikolojik İhtiyaçlarını Öngörmede Egzersizde Davranışsal Düzenlemelerin ve Hedef Yöneliminin Rolü
}

\author{
The Role of University Students' Exercise Behavioral Regulation and Goal Orientation in \\ Predicting Their Basic Psychological Needs in Exercise
}

\author{
Gözde Ersöz* - Yaşar Özcan **
}

\begin{abstract}
The aim of this study is to investigate the role of university students' exercise behavioral regulation and goal orientation in predicting their basic psychological needs in exercise. There are 283 university student voluntarily participating in this study $\left(\mathrm{n}_{\text {male }}=156 ; X_{\text {age }}=20.64 \pm 3.58\right.$ ve $\left.n_{\text {female }}=127 ; X_{\text {age }}=19.65 \pm 4.10\right)$. Personal information form, "Goal Orientation in Exercise Questionnaire", "Behavioral Regulations in Exercise Questionnaire", "Basic Physiological Needs in Exercise Questionnaire" and "International Physical Activity Questionnaire (IPAQ)" were applied to the participants. Descriptive statistics analysis (mean and standard deviation), hierarchical regression analysis and Pearson Product Moment Correlation Analysis were used for analyzing the data. As a result of hierarchical regression analysis, while the task orientation with internal and introjected regulation, positively predicts the need for competence and autonomy on the other hand, external regulation has predicted competence negatively. Relatedness has been positively predicted by internal and introjected regulation and task and ego orientation. The physical activity levels of the participants were positively related to internal and introjected regulation and competence, autonomy and relatedness psychological needs. As a result, individuals who exercise by having fun and enjoying, internalizing, and setting goals while exercising satisfy their needs for competence, autonomy and relatedness. It has been observed that individuals who exercise for external reasons such as health and physical appearance, their competence needs were reduced in exercise. In addition, students who exercise by comparing themselves with others and have external targets rather than their own targets saticfied their relatedness needs in exercise. Another result of the study is that the university students who exercise by having fun and internalizing are satisfied their competence, autonomy and relatedness needs in exercise have a more active lifestyle.
\end{abstract}

\footnotetext{
* Doç. Dr., Tekirdağ Namık Kemal Üniversitesi, Beden Eğitimi ve Spor Yüksekokulu, Spor Yöneticiliği Bölümü Assoc. Prof. Dr., Tekirdağ Namık Kemal University, School of Physical Education and Sports 
Structured Abstract: It has been established by studies that physical inactivity is one of the main causes of many chronic diseases such as coronary heart disease, hypertension, arthritis rheumatism, chronic obstructive pulmonary disease, and even cancer (Byers et al., 2002; Hooper et al., 2001; Fritz et al., 2006; Kushner \& Mechanick, 2015). According to the estimations of World Health Organization (WHO); 70-80\% of mortality in the developed countries and 40-50\% of mortality in the developing countries is caused by diseases that originate from life style modes. Based on the health reports prepared in Turkiye; it is reported that $71 \%$ of total mortality occurs due to chronic diseases and seven of the top ten diseases that cause mortality are chronic diseases (Erkoç \& Yardım, 2011). According to a report prepared by Turkish Ministry of Health in 2014; when the distribution of 10 major health problems that individuals aged $\geq 15$ years suffered from in the last 12 months was investigated, it was seen that of chronic diseases, hypertension is ranked as the second, diabetes as the fifth, coronary health disease as the seventh and COPD as the eighth (Sağlık Bakanlığı, 2015). In order to prevent chronic diseases caused by inactive life style and to make people lead a healthier life style, it is important that psychological factors that are important in acquiring exercise habits be explored. One of the most important psychological concepts in acquiring exercise habits is motivation.

The aim of this study is to investigate the role of university students' exercise behavioral regulation and goal orientation in predicting their basic psychological needs in exercise. There are 283 university student voluntarily participating in this study $\left(\mathrm{n}_{\text {male }}=156 ; \mathrm{X}_{\mathrm{age}}=20.64 \pm 3.58\right.$ ve $\left.\mathrm{n}_{\text {female }}=127 ; \mathrm{X}_{\mathrm{age}}=19.65 \pm 4.10\right)$. Personal information form, "Goal Orientation in Exercise Questionnaire", "Behavioral Regulations in Exercise Questionnaire", "Basic Physiological Needs in Exercise Questionnaire" and "International Physical Activity Questionnaire (IPAQ)" were applied to the participants. Descriptive statistics analysis (mean and standard deviation), hierarchical regression analysis and Pearson Product Moment Correlation Analysis were used for analyzing the data. As a result of hierarchical regression analysis, while the task orientation with internal and introjected regulation, positively predicts the need for competence and autonomy on the other hand, external regulation has predicted competence negatively. Relatedness has been positively predicted by internal and introjected regulation and task and ego orientation. The physical activity levels of the participants were positively related to internal and introjected regulation and competence, autonomy and relatedness psychological needs. As a result, individuals who exercise by having fun and enjoying, internalizing, and setting goals while exercising satisfy their needs for competence, autonomy and relatedness. It has been observed that individuals who exercise for external reasons such as health and physical appearance, their competence needs were reduced in exercise. In addition, students who exercise by comparing themselves with others and have external targets rather than their own targets saticfied their relatedness needs in exercise. Another result of the study is that the university students who exercise by having fun and internalizing are satisfied their competence, autonomy and relatedness needs in exercise have a more active lifestyle.

It is a study-finding that individuals who think that they are sufficient in exercises do exercises due to intrinsic motivation such as fun and entertainment, avoiding from the feeling of guilt is positively associated with self-competence and answering competence needs reduces the tendency towards extrinsic motivation and increases task-orientation in exercises. Studies indicate that individuals' task orientation affects their selfcompetence and intrinsic motivation positively (Boyd, 2019; Zanatta et al., 2018). In a study done by Hagger and Chatzisarantis (2008), it is suggested that since introjected regulation is related to three basic psychological needs, it is argued that it is positively associated with task-orientation. Another finding obtained in this study was that participants that determined exercise-doing preference themselves did exercises due to intrinsic motivation such as fun and entertainment and joined exercises and focused on tasks because they would feel guilty when they did not exercise. In the studies that investigated basic psychological needs which were universally accepted and were proved to be effective in exercising behavior by these studies (Ntoumanis, 2005; Standage et al., 2005); it was explored that autonomous motivational orientation was positively connected with the three basic psychological needs (Hagger et al., 2006; Edmunds et al., 2007; Standage et al., 2007).It was another finding of the study that individuals who cared about friendship in exercise-environment and had fun doing exercises with others conducted exercises due to such intrinsic reasons as entertainment, joined exercises due to feeling of guilt, were task-oriented in exercise-environment and compared themselves to others in exercise-environment. Studies show that intrinsic motivation and self-determinated motivation orientation are positively associated with satisfying three basic psychological needs (Loiser et al., 1993; Vallerand \& Losier, 1999; Wilson et al., 2002). In the current study; it was identified that there was a positive correlation between PAL and psychological needs of competence, autonomy and relatedness and between introjected regulation, intrinsic regulation and motivational orientation whereas no correlation was found between extrinsic regulation

Turkish Studies - Social, 15(1) 
and amotivation and ego motivation orientation. That individuals who were physically active or continued exercises had higher introjected regulation supported basic principle of SDT. According to SDT, there was a positive correlation between self-determinated motivation and physical activity level (Chatzisarantis et al., 2003; Daley \& Duda, 2006; Edmunds et al., 2006; Frederick \& Ryan, 1993). There are also numerous studies that found that self-determinated motivation affected PAL positively. These results generally both support theoretical principle of SDT and were similar to the empirical findings in this field (Deci \& Ryan, 1985; Wilson et al., 2003). Additionally; those who were physically active had higher average introjected regulation (Chatzisarantis et al., 2003; Mullan \& Markland, 1997). Relevant literature contains findings that PAL affects introjected regulation positively. These studies concurred with the findings of the current study. Introjected regulation is placed at the end of self determination scale and represents less autonomous and controlled behaviors. Finding obtained in introjected regulation sub-scale was an unexpected result according to SDT; which may be explained through internalization and integrity concepts of SDT. In the current study; it was found that extrinsic regulation did not differ significantly among the participants in terms of physical activity level. On the other hand; previous studies reported results that extrinsic motivation affected PAL positively (Kamal ve Zulkifli, 2019; Alexandris et al., 2002; Frederick \& Ryan, 1993).

In line with the results of the study; it is recommended that those who work in exercise environment and run these facilities should provide participants with a participant-based counseling, provide them with an environment that support their autonomy in exercise, advise them correct exercise programs by identifying their physical suitability in order to eliminate the need for self-sufficiency in exercise, create a setting that makes exercise fun and determine correct objectives in exercise.

Keywords: Exercise Motivation, Self Determination Theory, Achievement Goal Theory, Basic Psychological Needs in Exercise.

Öz: Bu çalışmanın amacı, Tekirdağ Namık Kemal Üniversitesi’nde 2018-2019 eğitim-öğretim yılında öğrenim gören üniversite öğrencilerinin egzersizde temel psikolojik ihtiyaçlarını öngörmede egzersizde davranışsal düzenlemelerin ve hedef yöneliminin rolünü incelemektir. Araştırmada ayrıca fiziksel aktivite düzeyi ile egzersizde temel psikolojik ihtiyaçlar, davranışsal düzenlemeler ve hedef yönelimi ilişkisi araştırılmıştır. Araştırmaya 283 üniversite öğrencisi $\left(n_{\text {erkek= }} 156 ; X_{\text {yaş }}=20.64 \pm 3.58\right.$ ve $\left.n_{\text {kadın }}=127 ; X_{\text {yaş }}=19.65 \pm 4.10\right)$ gönüllü olarak katılmıştır. Katılımcılara kişisel bilgi formu, "Egzersizde Hedef Yönelimi Ölçeği (EHYÖ)", "Egzersizde Davranışsal Düzenlemeler Ölçeği (EDDÖ)" ve "Egzersizde Temel Psikolojik İhtiyaçlar Ölçeği (ETPİÖ)" ve "Uluslararası Fiziksel Aktivite Anketi (UFAA)" uygulanmıştır. Verilerin analizinde betimsel istatistik analizi (ortalama ve standart sapma), hiyerarşik regresyon analizi ve Pearson Momentler Çarpım Korelasyon analizi kullanılmıştır. Araştırmanın bulguları incelendiğinde hiyerarşik regresyon analizi sonucunda, içsel ve içe atımla düzenleme ile görev yönelimi yeterlik ve özerklik ihtiyacını pozitif yönde yordarken; dışsal düzenleme yeterlik ihtiyacını negatif yönde öngörmüştür. İlişkili olma ihtiyacı ise içsel ve içe atımla düzenleme ile görev ve ego yönelim tarafından pozitif yönde öngörülmüştür. Katılımcıların fiziksel aktivite düzeyleri içsel ve içe atımla düzenleme ve yeterlik, özerklik ve ilişkili olma psikolojik ihtiyaçları ile pozitif ilişkili bulunmuştur. Sonuç olarak, egzersizi eğlenerek ve zevk alarak, içselleştirerek yapan bireyler ve egzersiz yaparken hedefler koyan kişilerin egzersiz yaptıklarında yeterlik, özerklik ve ilişkili olma ihtiyaçlarını tatmin ettikleri; sağlık, fiziksel görünüm gibi dışsal sebeplerle egzersiz yapan bireylerin egzersizde yeterlilik ihtiyaçlarının azaldığı; egzersizi kendisini başkalarıyla karşılaştırarak yapan, kendi hedeflerinden çok dışsal hedefler koyan bireylerin de egzersizde ilişkili olma ihtiyacını karşıladıkları görülmüştür. Araştırmanın bir diğer sonucu ise egzersizi eğlenerek ve içselleştirerek yapan bireyler ile egzersizde yeterlik, özerklik ve ilişkili olma ihtiyaçlarının tatmin eden üniversite öğrencilerinin daha aktif bir yaşam tarzına sahip olduklarıdır.

Anahtar Kelimeler: Egzersizde Motivasyon, Hür İrade Kuramı, Hedefi Gerçekleştirme Kuramı, Egzersizde Temel Psikolojik İhtiyaçlar

\section{Giriş}

Egzersizin fiziksel, psikolojik ve sosyal faydaları herkes tarafından bilinmektedir (Haskell vd., 2007; Kanamori vd.,2015). Egzersizin faydaları bilinmesine rağmen dünya genelinde insanların egzersiz alışkanlığının düşük düzeyde olduğu yapılan araştırmalarla ortaya konulmuştur (USDHHS, 
2008). Son zamanlarda egzersiz davranışında güdüsel yönelimleri anlamaya yönelik çalışmalar sosyal bilişsel perspektiften ele alındığı görülmektedir (Ingledew ve Markland, 2008; Hagger ve Chatzisarantis, 2007; Brunet ve Sabiston, 2011).

Önceki çalışmalar temel psikolojik ihtiyaçların (özerklik, yeterlik ve ilişkili olma) tatmininin egzersiz ve spor ortamlarında uyumlu birçok davranış ile olumlu ilişki gösterdiğini ortaya koymuştur. Bunlar; özerk güdüsel yönelim (Sylvester vd., 2018), pozitif duygu durumu (Mack vd., 2011), zindelik (Adie vd., 2008), kendini fiziksel algilama (Sebire vd., 2009), eğlence (Álvarez vd., 2009), sabır ve efor (Smith vd., 2011) ve egzersizde devamlılık (Sylvester vd., 2018) şeklindedir. Spor ve egzersiz ortamlarında temel psikolojik ihtiyaçların olumsuz ilişki gösterdiği kavramlar ise sürantrenman septomları ve negatif duygu durumudur (Bartholomew vd., 2011; Lonsdale vd., 2008).

Egzersizde motivasyon konusunda sıklıkla kullanılan kuramların başında Hür İrade Kuramı (HIK), Temel Psikolojik İhtiyaçlar Kuramı (TPİK) ve Hedefi Gerçekleştirme Kuramı (HGK) gelmektedir (Nicholls, 1984; 1989). Bu çalışmada egzersiz davranışı sosyal bilişsel perspektiften ele alınmıştır ve araştırmada temel oluşturan kuramlara ilişkin açıklamalara aşağıda yer verilmiştir:

\section{Hür İrade Kuramı (Self-Determination Theory)}

Hür İrade Kuramı (HİK) (Deci ve Ryan, 1985) egzersiz davranışındaki güdüsel yönelimi anlamada popüler bir yaklaşım olarak karşımıza çıkmaktadır. HİK çok boyutlu bir yaklaşım benimsemektedir. Bireylerin belli davranış için güdülenmelerinin özerk mi yoksa kontrollü mü olduğunu araştırırken; insanların bazılarının pozitif ve sağlıklı davranışlar benimserken, diğerlerinin neden bu davranışları benimsemediğini açıklamaya çalışır. HİK' nın temel odağı, insan güdülenmesinin bir düzlem arz ettiği ve bu düzlemde yer alan çeşitli davranış kalıplarının bulunduğudur. Bu düzlem, egzersize katılım ile ilgili kararlarda özerk nedenlerden kontrol edilebilir nedenlere doğru ilerlemektedir. Burada en temel davranış belirleyici içsel güdülenmedir. Hareketin dış belirleyici olan ödüller ve tehditler tarafindan kontrol edilen dışsal güdülenme, bu düzlemdeki kontrollü davranışları temsil eder. Deci ve Ryan (1985), düzlemdeki çeşitli belirleyicilerin varlığı yanında bir de "güdülenmeme" durumunun yer aldığını ifade eder ve güdülenmeme bu düzleminin en sonunda yer alır (Yeltepe, 2007). İçsel güdülenme, bir aktiviteyle sadece o aktivitenin kendisi için, o aktiviteden alınan zevk için ilgilenme dürtüsüdür. İçsel olarak motive olduğumuzda hedef davranışa karşı samimi bir ilgimiz vardır. Bunun tam aksi ise dışsal güdülenmedir. Dışsal güdülenme bir aktiviteyle aktivitenin kendisinden çok onun aracılığıyla elde edeceğimiz bir şey, ulaşacağımız ya da kaçınacağımız bir sonuç için ilgilendiğimiz durumdur (Vallerand ve Fortier, 1998).

İçsel olarak güdülenildiğinde, bireyler bir aktiviteyle uğraşmaktan zevk alır (örneğin egzersiz yapıyorum çünkü eğlenceli). İlgili oldukları etkinliği sevdikleri ve daha iyi öğrenmek istedikleri için egzersiz yapan bireyler ya da ilgilendikleri spor dalında kendilerini aşmaktan özel bir haz alan bireyler içsel olarak güdülenmiş olarak değerlendirilirler (Pelletier vd., 1995). Hür-irade skalasına paralel olarak bulunan dışsal güdülenme, önceleri içsel güdülenmenin tam zıddı olarak ele alınmıştır ama bunu öne süren çalışmaların aksine HİK, dışsal güdülenmeden kaynaklanan eylemlerin yine hür-irade ve kontrol altındaki irade arasında değişen bir skalada kendini gösterdiğini ileri sürmektedir (Deci ve Ryan, 2000). Bu farklılıklar hakkında daha detaylı bilgi verebilmek için Deci ve Ryan Organizmaya Yönelik Bütünleşme Teorisi'ni ortaya atmışlardır. Bu teori ise içselleştirme ve bütünleştirmeye dayanır. Bu süreç, insanların bir değeri alıp ilerleyen zaman içinde kendi içlerinden çıkmış bir fikir gibi benimser hale gelişlerini anlatır. Diğer bir deyişle önceleri dışsal bir nedenle kontrollü yapmış olduğumuz davranış zamanla içselleştirilip özerk forma yakın bir hale getirebilir. Deci ve Ryan (1985) bu anlamda; bütünleşmiş, özdeşimle, içeatımla ve dişsal düzenleme şeklinde dört farklı tipte dışsal güdülenmeden bahsederler.

Bütünleşmiş düzenleme, içlerinde en özerk olandır ve dışsal güdülenme tarafından en az yönlendirilendir çünkü belli bir aktiviteyle uğraşmak kişinin kendi tercihi olmamakla birlikte, kişi onu kendi bünyesiyle uyumlu bir hale getirebilmiştir. Bu tür bir güdülenme aslında içsel 
güdülenmeye oldukça benzer fakat sonuç olarak başlangıç noktası kişinin kendi isteği değil dıştan gelen bir sebeple belli bir sonuç elde etme dürtüsüdür. Özdeşimle düzenleme, kişinin bir davranış1 değerlendirip önemli olduğu sonucuna vardıktan sonra o davranışı göstermeye başladığında karşımıza çıkar. Bu durumda da bir içselleştirme söz konusudur, fakat sonuçta yine odak noktası bir sonuç ya da ortaya çıkacak bir üründür. Bir sporla uğraşmalarının temel nedeni bu sporun kendi fiziksel gelişimlerine katkısı olduğunu düşünen bireyler bu duruma örnek olarak verilebilir. İçe atımla düzenleme, söz konusu olduğunda ise suçlu hissetmekten ya da endişeden kaçış, gurur gibi egodan kaynaklanan sebeplerle bir davranışı gösterme gereği duyulur. Tüm bunlar esasen içten kaynaklanan durumlar gibi görünse de neden sonuç ilişkisi açısından incelendiğinde kaynağı kişinin özünde değil dışarıdadır. Sporla uğraşmadıklarında mahcup ya da suçlu hissedecekleri için sporla uğraşan bireyler bu türden bir güdülenmeye sahiptir. Dışsal düzenleme ise hür-iradenin en az etkisini gösterdiği bir güdülenme biçimine işaret eder ve davranışa verilecek olan ödüller yada davranış gerçekleşmediğinde mahrum kalınacak şeyler sebebiyle oluşur. Övgü kazanmak veya sağlikla ilgili bir sorun yaşadıkları için egzersiz yapan bireyler bu gruba örnek oluştururlar (Kingston vd., 2006). Sonuç olarak, içsel, bütünleştirilmiş ve özdeşimle düzenlemeler hür-iradeli (özerk) güdüsel davranışları temsil ederken; içe atımla ve dışsal düzenlemeler düşük düzeyde hür-iradeli veya kontrol eden güdüsel düzenlemelerdir (Ntoumani ve Ntoumanis, 2006). Hür-irade skalasının en sonunda yer alan güdülenmeme ise, hem içsel hem de dışsal güdülenmenin eksikliğini ifade etmektedir ve bir etkinliğe değer vermemeyi gösterir veya birey bu etkinlikle istediği sonuçlara ulaşacağına inanmamaktadır. Güdülenmeme, motivasyondan yoksun olma durumu olduğu gibi aynı zamanda hür-iradeli durumun da olmadığı bir durumdur. Güdülenmeyen bir bireyin o egzersiz programına devam etmek için bir nedeni kalmamaktadır (Vallerand, 2001).

Spor ve egzersiz ortamlarında yapılan araştırmalar, içsel güdülenmenin uğraşılan etkinlikte devamlılığın sağlanmasında dışsal güdülenmeden daha etkili olduğunu göstermektedir. Örneğin, yüksek seviyedeki içsel güdülenme aktiviteden zevk alma, uğraştığı etkinlikte daha iyi olma, egzersizde devamlılığı sağlama, daha yoğun bir konsantrasyon ve daha iyi bir performansla ilgiliyken; yüksek seviyedeki dışsal güdülenme egzersiz yapan bireylerde kaygı ve egzersizde devamlılığın sağlanamaması ile bağdaşlaştırılmıştır (Kingston vd., 2006).

\section{Temel İhtiyaçlar Kuramı (Basic Psychological Needs Theory):}

HİK' nın altında yatan varsayıma göre insanlar kalıtımsal olarak sosyal çevrelerini oluşturmaya meyillidirler ve özerklik, yeterlilik ve ilişkili olma gibi ihtiyaçlarını gidermeye çalışırlar. İhtiyaçlar terimi genel olarak bireylerin bilinçli isteklerini, arzularını ve güdülerini yansıtmaktadır. Dolayısıyla ihtiyaçlar, kişinin ihtiyacının gücüne göre bireyler arasındaki farklılıkları ortaya koyan değiş̧kenlerdir. HïK kapsamında insanların özerklik, yeterlik ve ilişkili olma olarak adlandırılan üç temel ihtiyacı vardır (Özer, 2009).

Özerklik (Autonomy); özgürlük, bağımsızlık, kontrol gibi kavramlarla bazen eş anlamlı, bazen birlikte kullanılabilen özerklik kavramı, birbirine zıt istek ve eğilimler arasından seçim yapabilme gücü, dışsal kontrolden görece bağımsız olmak şeklinde tanımlanmaktadır. Yeterlik (Competence); yeterlik, bir işi yapmak için gerekli olan güce, bilgiye, beceriye sahip olma ve yapabileceğine inanma olarak tanımlanmaktadır ve istenilen sonuçlara ulaşmayı ve görevleri yerine getirmeyi içerir. İlişkili Olma (Relatedness); bireylerin başkaları ile ilişki kurma ihtiyacı ve içinde bulundukları sosyal çevreye ait olma duygusunu yaşamalarıdır.

HİK güdülenme ve psikolojik ihtiyaçların ilişkisini açıklayarak bir iskelet oluşturmaktadır. İnsanların içinde bulundukları çevre özerklik, yeterlik ve ilişkili olma algıları üzerinde etkilidir dolayısıyla bu temel psikolojik ihtiyaçlar güdülenme üzerinde belirleyici olmaktadır. Bireylerin temel psikolojik ihtiyaçlarını tam olarak doyurabilmeleri için yaşantılarındaki etkinlikleri kendileri özgürce seçmelidirler ki seçilen etkinlik zevk veren, hoşlanılan bir hale gelebilsin. Ancak bu şekilde olduğunda bireyler etkinliğe içsel olarak güdülenebilmektedirler. Etkinlik temel ihtiyaçları 
doyurmadığında, kişi etkinliği yapmaya devam edebilmekte, ama içsel olarak güdülenmemektedir. Bunun dışında sosyal çevrenin vereceği özerklik desteği de bireyin davranışlarını kendisinin kontrol etmesini sağladığı için içsel güdülenmeyi harekete geçirmektedir (Çankaya, 2005).

HİK' nda kişilerin kendilerini özerk ve yeterli hissetmelerinin, onların içsel olarak güdülenmeleri üzerinde olumlu etki olacağı ileri sürülmektedir (Markland, 1999). Ayrıca bu kurama göre, içsel güdülenme ile özerklik ve yeterlik algısı arasındaki etkileşim olumlu yönde ve yüksek iken, ilişkili olma arasındaki ilişkinin etkisi daha azdır (Çankaya, 2005). Yeterlik algısının ise içsel güdülenme üzerinde etkisi büyüktür (Losier ve Vallerand, 1994).

$\mathrm{Bu}$ ihtiyaçlarımız doyurulduğunda güdüsel düzenlemelerin hür-iradeli şekilleri (içsel, bütünleştirilmiş ve özdeşimle) egzersiz davranışına uyum sağlamamızı sağlamaktadır. Bu durumun tam tersi olarak bu ihtiyaçlar doyurulmadığı zaman kontrollü güdülenmeye (içe atımla ve dışsal düzenleme ve güdülenmeme) neden olur ve bu durum bireyin egzersiz davranışına uyum sağlanmaması ile sonuçlanır (Deci ve Ryan, 1985; 2000).

Edmunds vd. (2006) temel ihtiyaçlar ile egzersizde davranışsal düzenlemeler arasındaki ilişkiyi araştırdıkları çalışmalarında, üç temel ihtiyacın giderilmesinin içsel ve özdeşimle düzenleme ile pozitif; dışsal güdülenme ile negatif ilişkili olduğunu ortaya koymuştur.

\section{Hedefi Gerçekleștirme Kuramı (Achievement Goal Theory)}

Hedefi Gerçekleştirme Kuramı (HGK), Dweck ve Leggett (1988) tarafindan ortaya atılmış ve insanların bir iş karşısında koydukları hedefler doğrultusunda ne derece motive olduklarını (Wagner, 2009) ve nasıl davrandıklarını incelemiştir. Başarı yönelimi ile ilgili araştırmacılar, ilk önce görev ve ego yönelimi şeklinde iki faktörlü modeli ortaya koymuşlardır. Bu modele göre, görev yönelimine sahip bireyler yetkinlikleri artırma, öğrenmeyi öncelikli görme, konuları daha iyi anlama, kendi performansını bir üst noktaya çıkarma gibi konularla ilgilenirken, ego yönelimine sahip olanlar diğerlerinden performansları hakkında olumlu şeyler duymak isteme, diğerlerinden daha iyi olma ve başarısız görünmemeye çalışma gibi niteliklere sahiptir (Pintrich ve Schunk, 1996).

Görev yönelimi üzerine spor ve beden eğitimi alanında yapılan araştırmalar içsel güdülenme ile görev yönelimi (Goudas vd., 1994; Duda vd., 1995) arasında olumlu bir ilişki; ego yönelimi ile ise tutarlı sonuçlar elde edememişlerdir (Ntoumanis ve Biddle, 1999). Bu konudaki diğer çalışmalarda ise ego yönelimin görev yönelimiyle birleştiğinde yüksek düzeyde güdülenmeye neden olacağını ileri sürülmüştür (Fox vd., 1994; Wang ve Biddle, 2001). Biddle vd. (1999) hedef yönelimi ile egzersizde güdüsel yönelim arasındaki ilişkiyi inceledikleri araştırmalarında içsel ve özdeşimle düzenleme ile görev yönelimi arasında pozitif ilişki olduğunu, ego yöneliminin dışsal düzenleme ve güdülenmeme ile negatif ilişkili olduğunu belirtmişlerdir. Fiziksel aktiviteye katılan ergen bireylerin güdüsel profillerinin incelendiği Wang ve Biddle (2001) ile Biddle ve Wang (2003) tarafindan yapılan araştırmada, görev yönelimi, algılanan yeterlik düzeyi yüksek olan, daha hür iradeli şekilde egzersiz davranışını sergileyenlerin egzersizde daha çok devamlılık sağladığı belirtilmiştir (Dyrlund, 2008).

Bu çalışmada güdülenme ile ilgili çalışmalarda sıklıkla ele alınan psikolojik kuramlardan HİK, TPİK ve HGK arasındaki ilişkinin egzersiz davranışındaki durumunu ortaya konmak istenmiştir. $\mathrm{Bu}$ doğrultuda egzersiz ortamlarında giderilen üç temel psikolojik ihtiyacın (yeterlik, özerklik ve ilişkili olma) yordanmasında egzersizde davranışsal düzenlemeler (içsel, içe atımla, dışsal düzenleme ve güdülenmeme) ile egzersizde hedef yöneliminin (görev ve ego yönelimi) etkisinin incelenmesi amaçlanmıştır. 


\section{Gereç ve Yöntem}

\section{Araştırmanın Modeli}

Araştırma genel tarama modelinden ilişkisel tarama modeli temel alınarak gerçekleştirilmiştir.

\section{Araștırma Grubu}

Araştırma grubu olasılıksız örneklem yöntemlerinden uygun örneklem yöntemi ile oluşturulmuştur. Çalışmaya lisans düzeyde eğitim gören 17-35 yaş aralığında 127 kadın (Xyaş= $19.65 \pm 4.10$ yıl), 156 erkek (Xyaş= 20.64 \pm 3.58 yıl) toplam 283 üniversite öğrencisi (Xyaş= $21.66 \pm 2.06$ yıl) gönüllü olarak katılmıştır.

\section{Veri Toplama Araçları}

$\mathrm{Bu}$ araştırmada kişisel bilgi formu, "Egzersizde Temel Psikolojik İhtiyaçlar Ölçeği (ETPIÖ)", "Egzersizde Davranışsal Düzenlemeler Ölçeği (EDDÖ)" ve "Egzersizde Hedef Yönelimi Ölçeği (EHYÖ)" katılımcılara uygulanmıştır. Araştırmada kullanılan kişisel bilgi formu ve ölçeklere ilişkin bilgiler aşağıda açıklanmıştır.

\section{Kişisel Bilgi Formu}

Kişisel bilgi formu 7 maddeden oluşmaktadır ve sırasıyla katılımcının cinsiyeti, yaşı, egzersiz türü, egzersiz sıklığı, şiddeti, süresi, kaç yıldır egzersiz yaptığı ilişkin bilgileri toplamak amacıyla hazırlanmıştır.

\section{Egzersizde Temel Psikolojik İhtiyaçlar Ölçeği (ETPIÖ)}

Hür İrade Kuramı kapsamında insanların özerklik, yeterlik ve ilişkili olma olarak adlandırılan üç temel ihtiyacını egzersiz ortamında değerlendirmek üzere Vlachopoulos ve Mchailidou (2006) tarafindan geliştirilmiştir. ETPÏÖ, 12 madde ve 3 alt boyuttan (yeterlik, özerklik ve ilişkili olma) oluşmaktadır. Ölçeğin Türkçe' ye uyarlaması Vlachopoulos vd., (2013) tarafından kültürler arası bir çalışmayla yapılmış olup "Tamamen Katılmıyorum" (1) ile "Tamamen Katılıyorum" (5) derecelerinden oluşan 1-5 arasında puanlaması olan 5'li Likert tipi ölçek kullanılarak değerlendirilmektedir. ETPİÖ' nün uyum indeks değerleri uygun bulunmuştur $\left(X^{2}(42)\right.$ $=284,57, \mathrm{p}<.01 ; \mathrm{CFI}=0,912$; RMSEA $=0,074)$ ve faktör yükleri 12 maddeli ölçek için faktör yükleri 0,64 ile 0,76 arasında değişmiştir. Ölçeklerin güvenirliğini test etmek amacı ile Cronbach alfa iç tutarlık katsayısı hesaplanmıştır. ETPİÖ için hesaplanan iç tutarlık katsayıları 0,73 (Yeterlik) ile 0,80 (ilişskili olma) arasında bulunmuştur (Vlachopoulos vd., 2013). Bu çalışmada elde edilen iç tutarlılık katsayıları ise yeterlik için 0.86 ; ilişkili olma için 0.83 ; özerklik için 0.78 olarak bulunmuștur.

\section{Egzersizde Davranışsal Düzenlemeler Ölçeği-2 (EDDÖ-2)}

Hür İrade Kuramı kapsamında güdüsel yönelimlerini belirlemek için kullanılmak üzere geliştirilen EDDÖ-2, 19 madde ve 4 alt boyuttan (içsel düzenleme, içe atımla düzenleme, dışsal düzenleme ve güdülenmeme) oluşmaktadır. EDDÖ-2 "Kesinlikle Doğru Değil”, "Bazen Doğru” ve "Kesinlikle Doğru" derecelerinden oluşan 0-4 arasında puanlaması olan 5'li Likert tipi ölçek kullanılarak değerlendirilmektedir. EDDÖ, Mullen vd., (1997) tarafindan geliștirilmiș, Markland ve Tobin (2004) tarafindan revize edilmiş olup (EDDÖ-2), Türkçe formunun geçerlik ve güvenirlik çalışması Ersöz vd., (2012) tarafından yapılmıştır. EDDÖ-2' nin Türkçe formunda, orijinal formundan farklı olarak Özdeşimle Düzenleme alt boyutu yer almamıştır. EDDÖ-2 için hesaplanan iç tutarlık katsayıları 0.67 (Dışsal Güdülenme) ile 0.81 (Íçsel Düzenleme) arasında bulunmuştur (Ersöz vd., 2012). Bu çalışmada elde edilen iç tutarlılık katsayıları ise içsel düzenleme için 0.83; içe atımla düzenleme için 0.84; dışsal düzenleme için 0.77; güdülenmeme alt boyutu için 0.80 olarak bulunmuştur. 


\section{Egzersizde Hedef Yönelimi Ölçeği (EHYÖ)}

Başarı Hedefi Kuramı kapsamında egzersiz hedeflerini belirlemek için kullanılmak üzere geliştirilen EHYÖ, 10 madde ve 2 alt boyuttan (görev ve ego yönelimi) oluşmaktadır. EHYÖ "Tamamen Katılmıyorum" ve "Tamamen Katıliyorum" derecelerinden oluşan 1-5 arasında puanlaması olan 5'li Likert tipi ölçek kullanılarak değerlendirilmektedir. EHYÖ, Petherick ve Markland (2008) tarafından geliştirilmiş, Türkçe formunun geçerlik ve güvenirlik çalışması Ersöz vd., (2017) tarafından yapılmıştır. EHYÖ uyum indeks değerleri uygun bulunmuştur $\left(\chi_{(34)}^{2}=62,48\right.$; $\mathrm{CFI}=0,98 ; \mathrm{RMSEA}=0,045)$. Ölçeğin test tekrar test sonuçları görev yönelimi için 0,90 ; ego yönelimi için ise 0,87 olarak belirtilmiştir. GOEM için hesaplanan iç tutarlık katsayıları görev yönelimi için 0.78; ego yönelimi için 0,88 olarak hesaplanmıştır (Ersöz vd., 2017). Bu çalışmada elde edilen iç tutarl1l1k katsayıları ise ego yönelimi için 0.88 , görev yönelimi için ise 0.90 olarak bulunmuştur.

\section{Uluslararası Fiziksel Aktivite Anketi}

Uluslararası fiziksel aktivite anketi (UFAA), Craig, Marshall, Sjostrom, Bauman, ve Booth (2003) tarafından 12 farklı ülkede geçerlik ve güvenirlik çalışması yapılarak geliştirilmiştir. UFAA 18-65 yaş arasındaki bireylerin fiziksel aktivite düzeylerini belirlemeye yönelik geliştirilen geçerli bir araçtır (Craig vd., 2003). Türkçe'ye uyarlaması Öztürk (2005) tarafından yapılan anketin sekiz versiyonu vardır. Bu çalışmada "son 7 gün" kısa formu kullanılmıştır. Anketin (kısa formu) kriter geçerlik değeri $(\mathrm{r}=0.30)$, ve test tekrar test güvenirliği $(\mathrm{r}=0.69)$ olarak hesaplanmıştır. Kısa form $(7$ soru), yürüme, orta-şiddetli ve şiddetli aktivitelerde harcanan zaman hakkında bilgi sağlamaktadır. Oturmada harcanan zaman ayrı bir soru olarak değerlendirilmektedir (Öztürk, 2005). Kişinin fiziksel aktivite düzeyini, yapılan hareketin süre, sıklık ve yoğunluk düzeyine göre MET cinsinden hesaplayarak düşük, orta ve yüksek düzey şeklinde sınıflandırılmaktadır (Cengiz vd., 2010).

\section{Verilerin Analizi}

Araştırmada elde edilen veriler SPSS paket programına aktarılmıştır. Verilerin analizinde araştırma grubunun özelliklerinin tanımlanması için betimsel istatistik analizi (ortalama ve standart sapma) yapılmıştır. Araştırmada yer alan bireylerin egzersizde güdüsel yönelimleri ile egzersizde hedef yöneliminin egzersizde temel psikolojik ihtiyaçları yordayıp yordamadığı hiyerarşik regresyon analizi ile sınanmıştır. Verilerin analizine ve bulguların yorumlanmasına geçilmeden önce normallik, doğrusallık, çoklu ve varyans-kovaryans matrislerinin homojenlik varsayımların karşılanıp karşılanmadığı incelenmiştir (Tabachnick ve Fidell, 2013). Bağımlı değişkenler arasında ilişkilerin doğrusal olup olmadığı saçılım grafikleri aracılığı ile incelenmiş ve her bağımlı değişken arasında doğrusallık varsayımının karşılandığı görülmüsstür. Regresyonun dayandığı bir başka önemli varsayım ise bağımlı değişkenler arasında doğrusal bir ilişki olması (linearity) ancak bu ilişkinin yüksek olmamasıdır (colinearity). Tahmin değişkenleri olasılığı kontrolü için tüm faktörlerde tolerans (TOL) ve varyans enflasyon faktörü (VIF) değerleri hesaplanmıştır. Katılımcıların egzersizde hedef yönelimi ile davranışsal düzenlemeler ve temel psikolojik ihtiyaçlar alt boyutları arasındaki ilişki Pearson çarpım-moment korelasyon analizi ile sınanmıştır. 


\section{Bulgular}

Tablo 1: Egzersizde temel psikolojik ihtiyaçlardan «yeterlik» ihtiyacının egzersizde motivasyonel yönelimler ve hedef yönelimini ne düzeyde öngördüğüne ilişkin bulgular

\begin{tabular}{|c|c|c|c|c|c|c|c|}
\hline & $\boldsymbol{\beta}$ & $\mathbf{t}$ & $\mathbf{p}$ & VIF & $\mathbf{R}$ & $\mathbf{R}^{2}$ & $\mathbf{F}$ \\
\hline \multicolumn{8}{|l|}{ 1.Model } \\
\hline İçsel düzenleme & .695 & 8.395 & $.000 * * *$ & 1.765 & \multirow{4}{*}{.681} & \multirow{4}{*}{0.464} & \multirow{4}{*}{60.19} \\
\hline İçeatımla düzenleme & .169 & 3.582 & $.000 * * *$ & 1.615 & & & \\
\hline Dişsal düzenleme & -.152 & -2.194 & $.029 *$ & 1.755 & & & \\
\hline Güdülenmeme & -.055 & -.697 & .487 & 1.903 & & & \\
\hline \multicolumn{8}{|l|}{ 2.Model } \\
\hline İçsel düzenleme & .584 & 7.169 & $.000 * * *$ & 1.885 & \multirow{6}{*}{.719} & \multirow{6}{*}{0.517} & \multirow{6}{*}{15.19} \\
\hline İçeatımla düzenleme & .133 & 2.934 & $.004 * *$ & 1.652 & & & \\
\hline Dişsal düzenleme & -.136 & -2.028 & $.044 *$ & 1.804 & & & \\
\hline Güdülenmeme & .021 & .269 & .788 & 1.967 & & & \\
\hline Ego & .003 & .395 & .693 & 1.091 & & & \\
\hline Görev & .074 & 5.298 & $.000 * * *$ & 1.464 & & & \\
\hline
\end{tabular}

Yeterlik temel psikolojik ihtiyacını yordayan değişkenleri belirlemek amacı ile yapılan hiyerarşik çoklu regresyon analizi Tablo 1' de verilmiştir. Yeterlik alt ölçeğini yordayan değişkenleri belirlemek için, iki adımda gerçekleştirilen hiyerarşik regresyon analizinde; birinci adımda egzersizde davranışsal düzenlemeler değişkenleri, ikinci adımda ise egzersizde hedef yönelimleri alt boyutları girilmiştir.

Modele birinci adımda girilen içsel, içeatımla, dışsal düzenleme ve güdülenmemenin özgün katkısının model içerisinde anlamlı olduğu ve egzersizde davranışsal düzenlemelerin egzersizde yeterlik ihtiyacının \%46' sını açıladığı görülmektedir $\left(R=.68 ; R^{2}=.46\right.$; Düzeltilmiş $\mathrm{R}^{2}=-.46$; $\left.\mathrm{F}_{(4,282)}=60.19, \mathrm{p}<.001\right)$. Yapılan hiyerarşik regresyona analizi sonucunda, yeterlik ihtiyacı ile içsel düzenleme $(\beta=.70, \mathrm{p}<.001)$ ve içeatımla düzenleme $(\beta=.17, \mathrm{p}<.001)$ arasında pozitif yönde; dıssal düzenleme $(\beta=.-15, p<.05)$ ile negatif yönde ilişki olduğu, güdülenmeme $(\beta=-.06, p>.05)$ alt ölçeğinin ise yeterlik ihtiyacını yordama etkisinin anlamlı olmadığı bulunmuştur.

Modele ikinci adımda girilen egzersizde hedef yönelimi alt boyutlarının (ego ve görev yönelimi) özgün katkısı model içerisinde anlamlıdır ve egzersizde davranışsal düzenlemelerle birlikte egzersizde yeterlik ihtiyacının $\% 51$ ' ini açıklamaktadır $\left(\mathrm{R}=.72 ; \mathrm{R}^{2}=. .52\right.$; Düzeltilmiş $\mathrm{R}^{2}=.51$; $\left.\mathrm{F}_{(6,282)}=15.19, \mathrm{p}<.001\right)$. Yapılan hiyerarşik regresyona analizi sonucunda, yeterlik ihtiyacı ile görev yönelimi $(\beta=.07, p<.001)$ arasında pozitif yönde ilişki olduğu ego yöneliminin $(\beta=.00, p>.05)$ ise yeterlik ihtiyacını yordama etkisinin anlamlı olmadığı bulunmuştur. 
Tablo 2: Egzersizde temel psikolojik ihtiyaçlardan «özerklik» ihtiyacının egzersizde motivasyonel yönelimler ve hedef yönelimini ne düzeyde öngördüğ̈̈ne ilişkin bulgular

\begin{tabular}{|c|c|c|c|c|c|c|c|}
\hline & $\beta$ & $\mathbf{t}$ & p & ViF & $\mathbf{R}$ & $\mathbf{R}^{2}$ & $\mathbf{F}$ \\
\hline \multicolumn{8}{|l|}{ 1.Model } \\
\hline İçsel düzenleme & .513 & 6.941 & $.000 * * *$ & 1.765 & & & \\
\hline İçeatımla düzenleme & .230 & 5.457 & $.000^{* * *}$ & 1.615 & .686 & 0.471 & 61.88 \\
\hline Dışsal düzenleme & -.122 & -1.971 & .050 & 1.755 & & & \\
\hline Güdülenmeme & -.078 & -1.104 & .270 & 1.903 & & & \\
\hline \multicolumn{8}{|l|}{ 2.Model } \\
\hline İçsel düzenleme & .425 & 5.777 & $.000 * * *$ & 1.885 & & & \\
\hline İçeatımla düzenleme & .200 & 4.896 & $.000^{* * *}$ & 1.652 & & & \\
\hline Dışsal düzenleme & -.111 & -1.839 & .067 & 1.804 & .717 & 0.514 & 12.19 \\
\hline Güdülenmeme & -.017 & -.250 & .802 & 1.967 & & & \\
\hline Ego & .004 & .581 & .562 & 1.091 & & & \\
\hline Görev & .059 & 4.678 & $.000^{* * *}$ & 1.464 & & & \\
\hline
\end{tabular}

Özerklik temel psikolojik ihtiyacını yordayan değişkenleri belirlemek amacı ile yapılan hiyerarşik çoklu regresyon analizi Tablo 2' de verilmiştir. Özerklik alt ölçeğini yordayan değişkenleri belirlemek için, iki adımda gerçekleştirilen hiyerarşik regresyon analizinde; birinci adımda egzersizde davranışsal düzenlemeler değişkenleri, ikinci adımda ise egzersizde hedef yönelimleri alt boyutları girilmiştir.

Modele birinci adımda girilen içsel, içeatımla, dışsal düzenleme ve güdülenmemenin özgün katkısının model içerisinde anlamlı olduğu ve egzersizde davranıșsal düzenlemelerin egzersizde özerklik ihtiyacının \%46' sını açıkladığı görülmektedir $\left(\mathrm{R}=.69 ; \mathrm{R}^{2}=.47\right.$; Düzeltilmiş $\mathrm{R}^{2}=-.46$; $\left.\mathrm{F}_{(4,282)}=61.88, \mathrm{p}<.001\right)$. Yapılan hiyerarşik regresyona analizi sonucunda, özerklik ihtiyacı ile içsel düzenleme $(\beta=.51, \mathrm{p}<.001)$ ve içeatımla düzenleme $(\beta=.23, \mathrm{p}<.001)$ arasında pozitif yönde ilişki olduğu; dişsal düzenleme $(\beta=.-12, p>.05)$ ve güdülenmeme $(\beta=-.08, p>.05)$ alt ölçeklerinin ise özerklik ihtiyacını yordama etkisinin anlamlı olmadığı bulunmuştur.

Modele ikinci adımda girilen egzersizde hedef yönelimi alt boyutlarının (ego ve görev yönelimi) özgün katkısı model içerisinde anlamlıdır ve egzersizde davranışsal düzenlemelerle birlikte egzersizde özerklik ihtiyacının \%50' sini açıklamaktadır $\left(\mathrm{R}=.72 ; \mathrm{R}^{2}=.51\right.$; Düzeltilmiş $\left.\mathrm{R}^{2}=.50 ; \mathrm{F}_{(6,282)}=12.19, \mathrm{p}<.001\right)$. Yapılan hiyerarşik regresyona analizi sonucunda, yeterlik ihtiyac1 ile görev yönelimi $(\beta=.06, p<.001)$ arasında pozitif yönde ilişki olduğu ego yöneliminin $(\beta=.00$, $\mathrm{p}>.05$ ) ise yeterlik ihtiyacını yordama etkisinin anlamlı olmadığı bulunmuştur. 
Tablo 3: Egzersizde temel psikolojik ihtiyaçlardan «ilişkili olma» ihtiyacının egzersizde motivasyonel yönelimler ve hedef yönelimini ne düzeyde öngördügüne ilişkin bulgular

\begin{tabular}{|c|c|c|c|c|c|c|c|}
\hline & $\beta$ & $\mathbf{t}$ & $\mathbf{p}$ & ViF & $\mathbf{R}$ & $\mathbf{R}^{2}$ & $\mathbf{F}$ \\
\hline \multicolumn{8}{|l|}{ 1.Model } \\
\hline İçsel düzenleme & .507 & 5.188 & $.000^{* * * *}$ & 1.765 & & & \\
\hline İçeatımla düzenleme & .121 & 2.181 & $.030^{*}$ & 1.615 & .486 & 0.236 & 21.50 \\
\hline Dişsal düzenleme & -.063 & -.763 & .446 & 1.755 & & & \\
\hline Güdülenmeme & -.036 & -.382 & .703 & 1.903 & & & \\
\hline \multicolumn{8}{|l|}{ 2.Model } \\
\hline İçsel düzenleme & .405 & 4.200 & $.000 * * *$ & 1.885 & & & \\
\hline İçeatımla düzenleme & .078 & 1.460 & .145 & 1.652 & & & \\
\hline Dışsal düzenleme & -.076 & -.961 & .337 & 1.804 & .555 & 0.072 & 14.30 \\
\hline Güdülenmeme & .037 & .404 & 687 & 1.967 & & & \\
\hline Ego & .023 & 2.736 & $.007 * *$ & 1.091 & & & \\
\hline Görev & .065 & 3.930 & $.000^{* * * *}$ & 1.464 & & & \\
\hline
\end{tabular}

İlişkili olma temel psikolojik ihtiyacını yordayan değişkenleri belirlemek amacı ile yapılan hiyerarşik çoklu regresyon analizi Tablo 3' de verilmiştir. İlişkili olma alt ölçeğini yordayan değişkenleri belirlemek için, iki adımda gerçekleştirilen hiyerarşik regresyon analizinde; birinci adımda egzersizde davranışsal düzenlemeler değişkenleri, ikinci adımda ise egzersizde hedef yönelimleri alt boyutları girilmiştir.

Modele birinci adımda girilen içsel, içeatımla, dışsal düzenleme ve güdülenmemenin özgün katkısının model içerisinde anlamlı olduğu ve egzersizde davranışsal düzenlemelerin egzersizde ilişkili olma ihtiyacının \%23' ünü açıkladığı görülmektedir $\left(\mathrm{R}=.49 ; \mathrm{R}^{2}=.24\right.$; Düzeltilmiş $\mathrm{R}^{2}=-.23$; $\left.\mathrm{F}_{(4,282)}=21.50, \mathrm{p}<.001\right)$. Yapılan hiyerarşik regresyona analizi sonucunda, ilişkili olma ihtiyacı ile içsel düzenleme $(\beta=.51, \mathrm{p}<.001)$ ve içeatımla düzenleme $(\beta=.12, \mathrm{p}<.05)$ arasında pozitif yönde ilişki olduğu; dişsal düzenleme ( $(\beta=.-06, p>.05)$ ve güdülenmeme $(\beta=-.04, p>.05)$ alt ölçeklerinin ise ilişkili olma ihtiyacını yordama etkisinin anlamlı olmadığ 1 bulunmuştur.

Modele ikinci adımda girilen egzersizde hedef yönelimi alt boyutlarının (ego ve görev yönelimi) özgün katkısı model içerisinde anlamlıdır ve egzersizde davranışsal düzenlemelerle birlikte egzersizde ilişkili olma ihtiyacının \%29' unu açıklamaktadır $\left(\mathrm{R}=.56 ; \mathrm{R}^{2}=.31\right.$; Düzeltilmiş $\left.\mathrm{R}^{2}=.29 ; \mathrm{F}_{(6,282)}=14.30, \mathrm{p}<.001\right)$. Yapılan hiyerarşik regresyona analizi sonucunda, ilişkili olma ihtiyacı ile görev yönelimi $(\beta=.02, \mathrm{p}<.01)$ ve ego yönelimi $(\beta=.07, \mathrm{p}<0.001)$ arasında pozitif yönde ilişki olduğu bulunmuştur. Modelin birinci adımında ilişkili olma ihtiyacı ile pozitif yönde anlamlı ilişki göstere içeatımla düzenleme alt boyutu; modele ikinci adımda görev ve ego yöneliminin dahil olması ile beraber anlamlı bir ilişki göstermemiştir $(\beta=.08, \mathrm{p}>.05)$.

Tablo 4. Katılımcıların egzersizde motivasyonel yönelimleri, hedef yönelimi ve psikolojik ihtiyaçları ile fiziksel aktivite düzeyi arasındaki ilişki

\begin{tabular}{lc}
\hline Güdüsel Yönelimler & FAD \\
\hline İçsel düzenleme & $.234^{* *}$ \\
İçeatımla düzenleme & $.225^{* *}$ \\
Dişsal düzenleme & -.048 \\
Güdülenmeme & -.04 \\
\hline Yeterlik & $.285^{* *}$ \\
Özerklik & $.263^{* *}$ \\
İlişkili olma & $.196^{* *}$ \\
\hline Ego & .042 \\
Görev & .114 \\
\hline$* * * \mathrm{p}<0.01$ &
\end{tabular}


Katılımcıların egzersizde davranışsal düzenlemeler, temel psikolojik ihtiyaçlar alt boyutları, egzersizde hedef yönelimi ile fiziksel aktivite düzeyleri (FAD) arasındaki ilişki Pearson çarpımmoment korelasyon analizi ile sınanmıştır. Korelasyon analizine ait sonuçlar Tablo 4' de verilmiştir.

Tablo 4' de görüldüğü gibi içsel düzenleme ( $\mathrm{r}=.23, \mathrm{p}<0.01)$ ve içe atımla düzenleme ( $\mathrm{r}=.23$, $\mathrm{p}<0.01)$ ile FAD arasında pozitif anlamlı bir ilişki bulunmuştur. Buna ek olarak yeterlik $(r=.29$, $\mathrm{p}<0.01)$, özerklik $(\mathrm{r}=.26, \mathrm{p}<0.01)$ ve ilişkili olma $(\mathrm{r}=.20, \mathrm{p}<0.01)$ psikolojik ihtiyaçları ile FAD arasında olumlu ilişki görüşmüştür. Ego yönelimi $(r=.04, p>0.05)$ ve görev yönelimi $(r=.11, p>0.05)$ ile FAD arasında anlamlı bir ilişki görülmemiştir.

\section{Tartışma ve Sonuç}

Araştırmanın bulguları analiz edildiğinde bu çalışmadaki egzersiz katılımcılarının yeterlik psikolojik ihtiyacı ile içsel düzenleme ve içeatımla düzenleme ve görev yönelimi arasında pozitif; dışsal düzenleme arasında ise negatif anlamlı bir ilişki bulunmuştur. Egzersiz katılımcılarının özerklik psikolojik ihtiyacı ile içsel düzenleme ve içeatımla düzenleme ve görev yönelimi arasında pozitif anlamlı bir ilişki bulunmuştur. Egzersiz katılımcılarının ilişkili olma psikolojik ihtiyacı ile içsel düzenleme ve içeatımla düzenleme ve görev ile ego yönelimi arasında pozitif anlamlı bir ilişki bulunmuştur.

$\mathrm{Bu}$ çalışmadan elde edilen bulgular doğrultusunda, egzersizde yeterlik ihtiyacını gideren bireylerin egzersizi zevk, eğlence gibi daha içsel motivlerle yaptıkları görülmüştür. Buna ek olarak, egzersiz ortamında yeterlik ihtiyacını karşılayan bireylerin daha kontrollü güdülendiği yani, egzersize yapmadığı için suçluluk duymaktan kaçınmak veya dışsal nedenlerle egzersiz yaptığı gözlenmiştir. Çalışmadaki bir diğer bulgu yeterlik ihtiyacı ile görev yönelimi arasındaki pozitif ilişkidir. Yapılan araştırmalar da çalışmamızdan elde edilen bulgularla paralel olarak, bireylerin göreve odaklanmalarının onların yeterliğini ve içsel motivasyonlarını olumlu etkilediği yönündedir (Boyd, 2019; Zanatta vd., 2018). Bu konudaki literatürün çok büyük bir kısmı da üç temel psikolojik ihtiyacın tatmininin hür iradeli güdüsel yönelim ve içsel düzenleme ile pozitif ilişkili olduğu yönündedir (Dysvik vd., 2013; Sibley ve Bergman, 2018). Önceki çalışmalar, içsel düzenlemenin üç temel psikolojik ihtiyaç ile olumlu ilişkisinden dolaylı görev yönelimi ile olumlu ilişkili olacağını savunmuştur (Hagger ve Chatzisarantis, 2008; Kazak, 2018). Spor ortamında temel psikolojik ihtiyaçlar, motivasyonel düzenlemeler ve hedef yöneliminin birlikte araştırıldığı, Álvarez ve ark., (2009)' nın futbolcular üzerinde yapmış oldukları araştırmada üç temel psikolojik ihtiyaç ile görev yönelimi ve içsel düzenleme arasında pozitif ilişki bulunmuştur. Reinboth ve Duda (2006) da üniversiteli sporcular üzerinde yaptıkları araştırmada görev yöneliminin psikolojik ihtiyaçlar ile pozitif yönde ilişkili olduğunu belirtmişlerdir. Kazak (2018) tarafından egzersiz katılımcılarında görev yönelimi ve temel psikolojik ihtiyaçlar arasındaki ilişkinin araştırıldığ 1 çalışmada da benzer şekilde görev yönelimi ile temel psikolojik ihtiyaçlar arasında orta düzeyde pozitif ilişki tespit edilmiştir. Bu çalışmalardan elde edilen bulgular araştırmamızı destekler niteliktedir.

$\mathrm{Bu}$ çalışmadan elde edilen bir diğer bulgu ise egzersiz yapma tercihini kendisi belirlemiş olan diğer bir deyişle egzersiz ortamında özerklik ihtiyacını gideren katılımcıların egzersize daha çok eğlenmek, zevk almak gibi içsel; suçluluk ve pişmanlık duygusundan kaçmak için iceatımlı ve egzersize görev yönelimli nedenlerle katıldığ görülmüştür. Egzersiz davranışında etkili olduğu araştırmalarla ortaya konan ve evrensel olarak kabul görmüş olan temel psikolojik ihtiyaçlar (Ntoumanis, 2005; Standage vd., 2005) üzerine yapılan çalışmalar özerk güdüsel yönelimin üç temel psikolojik ihtiyaç ile olumlu ilişkisini ortaya koymuştur (Hagger vd, 2006; Edmunds vd., 2007; Standage vd., 2007). Bu araştırmadan elde edilen bulgulara benzer şekilde spor ortamlarında (Stenling vd.,2015; Heuze vd., 2018) ve egzersiz ortamlarında yapılan çalışmalar (Standage ve Ryan, 2019; Kazak Çetinkalp ve Lochbaum, 2018) özerklik temel psikolojik ihtiyacın tatmininin içsel güdüsel yönelim ve görev yönelimi ile pozitif ilişkili olduğu yönündedir (Kazak 2018). İçeatımlı düzenleme ise HİK skalasının sonlarında yer almakta ve daha az özerk yani kontrollü 
davranışları temsil etmektedir. İçeatımla düzenleme ve özerklik ihtiyacı arasında pozitif ilişkiyi ortaya koyan çalışmalar da literatürde mevcut olup; araştırmamızdaki bulguları desteklemektedir (Gast vd., 2011; Ntoumanis vd., 2017).

Egzersiz ortamında arkadaşlık ilişkisine önem veren ve başkalarıyla birlikte egzersiz yapmaktan keyif alan bireylerin egzersizden daha çok keyif almak gibi içsel nedenlerle egzersiz yaptığı, suçluluk duygusu ile egzersize katıldığı, egzersiz ortamından görev yönelimli olduğu ve egzersiz ortamında kendilerini başkalarıyla karşılaştırdığına yönelik bulgu da araştırmamızın bir diğer sonucudur. Araştırmalar içsel güdülenme ve hür-iradeli motivasyonel yönelimin üç temel psikolojik ihtiyacın tatmini ile pozitif ilişkili olduğu yönündedir (Loiser vd., 1993; Vallerand ve Losier, 1999; Wilson vd., 2002). Sibley ve Bergman (2018) tarafindan cross-fit egzersizine katılan bireyler üzerinde yapılan bir araştırmada ise bu çalışmada elde edilen bulgulardan farklı olarak özerklik ihtiyacı ile içsel güdüsel yönelim arasında herhangi bir ilişki bulunmamış fakat cross-fit etkinliği küçük grup egzersizlerinden oluşan bir faaliyet olduğu için bu etkinliğe katılanların ilişkili olma ihtiyacını fazlasıyla karşıladığı görülmüştür. HGK perspektifinden egzersizde temel psikolojik ihtiyaçlarının tatmini doğrultusunda yapılan çalışmalar incelendiğinde genel olarak egzersizde üç temel psikolojik ihtiyacın tatmininin görev yönelimli egzersiz katılımı pozitif yordadığ 1 yönünde sonuçlar görülmektedir (Verner-Filion vd., 2017; Wang vd., 2009).

Portekiz' de egzersiz katılımcılarının egzersizde temel psikolojik ihtiyaçlarının tatmininin engellenmesi ile egzersizde güdüsel yönelimler arasındaki ilişkinin araştırıldığı güncel bir çalışmada ise egzersiz katılımcılarının özerklik ve yeterlik ihtiyaçlarının engellenmesi arttırkça dışsal güdülenme ve güdülenmeme düzeylerinin de arttığı; ilişkili olma ihtiyacının engellenmesinin ise içeatımlı güdüsel yönelimi arttırtığı görülmüştür (Rodrigues vd., 2019).

Bu çalışmada FAD ile yeterlik, özerklik ve ilişkili olma psikolojik ihtiyaçları ile içsel ve içe atımla düzenleme motivasyonel yönelimi arasında pozitif ilişki görülürken; dışsal düzenleme ve güdülenmeme ve görev ve ego güdüsel yönelimi arasında herhangi bir ilişki bulunmamıştır. Fiziksel olarak aktif veya egzersizde devamlılığı olan bireylerin içsel düzenlemelerinin yüksek olması HíK' nın temel prensibini desteklemektedir. HİK' na göre hür-iradeli güdülenme ile fiziksel aktivite düzeyi arasında pozitif bir ilişki bulunmaktadır. Hür-iradeli güdülenmenin fiziksel aktivite düzeyini olumlu yönde etkilediğini ortaya koyan birçok çalışma da bulunmaktadır (Mahony vd., 2019; Sabiston vd., 2010; Rodrigues vd., 2018; Daley ve Duda, 2006; Edmunds vd., 2006). Bu sonuçlar, genellikle HiK' nın hem teorik prensibi desteklemekte hem de bu alandaki deneysel bulgular ile benzerlik göstermektedir (Deci ve Ryan, 1985; Wilson vd., 2003). Bu bulgular doğrultusunda, hür-iradeli davranışların FAD'ni arttıracağını, hür-iradeli olmayan davranışlar sergileyen bireylerin ise sedanter yaşam tarzını benimseyeceği söylenebilir. Buna ek olarak, fiziksel olarak daha aktif olanların içe atımla düzenleme ortalamalarının yüksek olduğu da görülmüştür. FAD'nin içe atımla düzenlemeyi, olumlu yönde etkilediğine dair bulgular literatürde mevcuttur (Brunet ve Sabiston, 2011; Chatzisarantis vd., 2003; Mullan ve Markland, 1997). Bahsi geçen araştırmalar çalışmamızdan elde edilen bulguları destekler niteliktedir. İçe atımla düzenleme hür-irade skalasının sonlarında yer almakta ve daha az özerk yani kontrollü davranışları temsil etmektedir. İçe atımla düzenleme alt ölçeğinde edilen bulgu HiK' na göre beklenmedik bir sonuçtur. Bu durum HİK' nda yer alan içselleştirme ve bütünleşme kavramları ile açıklanabilir. İçselleştirme, insanların değerlerini kabul etmelerini, bütünleşme ise kişinin kendi kendine daha ileri bir düzeyde değeri benimseyip benliğine katmasını içermektedir. İçe atımla düzenlenmiş diğer bir deyişle, kontrollü bir davranışın, içsel ve özerk davranışa dönüşmesinde, çevre önemli rol oynayabilmektedir (Ryan ve Deci, 2000). İçe atımla düzenlemede de çevre etkili bir faktördür. Bireyler egzersiz yapmadıkları takdirde hissedecekleri suçluluk duygusu veya kendilerini başarısız hissedecekleri için egzersiz davranışında bulunmuş ve sonrasında bu davranışı içselleştirip benimsemiş olabilirler. Bu noktadan hareketle, bu çalışmada ve önceki çalışmalarda belirtildiği gibi hem içe atımla hem de içsel düzenleme puanlarının yüksek olması olağandır. Bu çalışmada, fiziksel aktivite düzeyine göre katılımcılarda dışsal düzenlemenin 
anlamlı bir farklılık göstermediği bulunmuştur. Buna karşın, önceki çalışmalar dışsal güdülenmenin fiziksel aktivite düzeyini olumlu yönde etkilediğine dair sonuçlar elde etmişlerdir (Alexandris vd., 2002; Kamal ve Zulkifli, 2019; Yli-Piipari vd., 2012). Bu bulgular çalışmamızın bulgularını desteklememektedir. Egzersize başlamaya genellikle sağlik, fiziksel görünüm gibi dişsal nedenlerle karar verilmektedir (Ingledew vd., 1998; McAuley vd., 1991; Ryan vd., 1997). Dolay1siyla egzersizin ön basamaklarında daha az hür-iradeli veya dışsal yani kontrollü egzersiz davranış1 sergilenebilmektedir. Egzersiz yapılan süreçte birey yapmış olduğu etkinliği içselleştirebildiği takdirde egzersize bağlanma gerçekleşebilecektir. Bireylerin yaptıkları egzersizi kendi hür iradeleriyle belirlemeleri, severek ve zevk alarak yapmaları, yaptıkları egzersizde kendilerini yeterli ve becerikli hissetmeleri söz konusu etkinlikte devamlılığı sağlayan, bu etkinliğe bağlanmalarını kolaylaştıran bir durum olabilir. Araştırmadan elde edilen bir diğer bulgu ise katılımcıların FAD' nin görev ve ego yönelimi ile ilişkili olmadığ 1 yönündedir. Bu bulgunun aksine Murcia ve Coll (2006) yaşları 16-58 arasında değişen egzersiz katılımcılarında FAD' nin egzersizde görev yönelimi ile olumlu ilişkisi olduğunu saptamışlardır. Murcia vd., (2007) tarafından yapılan bir başka çalışmada da daha aktif olan bireylerin görev yöneliminin yüksek olduğu sonucuna varılmıştır. Araştırma bulgularının aksini ortaya koyan bir başka çalışmada ise hafif ve orta düzeyde egzersiz yapanların ego yönelimi yüksek bulunurken; yüksek düzeyde aktif olanların görev yönelimi ortalamaları daha çok bulunmuştur (Moreno vd., 2007). Bu kanıya önceki araştırmalarda belirtildiği üzere (Ryan vd., 1999; Wilson vd., 2004) görev yöneliminin içsel düzenleme ile olumlu ilişkisi sonucu FAD' nin arttırmasına bağlayabiliriz.

\section{Kaynakça}

Adie, J. W., Duda, J. L., \& Ntoumanis, N. (2008). Autonomy support, basic need satisfaction and the optimal functioning of adult male and female sport participants: A test of basic needs theory. Motivation and Emotion, 32, 189-199, https://doi.org/10.1007/s11031-008-9095-z

Alexandris, K., Tsorbatzoudis, C. and Grouios, G. (2002). Perceived Constraints on Recreational Sport Participation: Investigating their Relationship with Intrinsic Motivation, Extrinsic Motivation and Amotivation, Journal of Leisure Research, Vol. 34, No.3: 233-252. https://doi.org/10.1080/00222216.2002.11949970

Álvarez, M., Balaguer, I., Castıllo, I., Duda, J. (2009). Coach autonomy support and quality of sport engagement in young soccer players. Span. J. Psycol. 12: 138-148. https://doi.org/10.1017/s1138741600001554

Bartholomew, K.J., Ntoumanis, N., Ryan, R.M., Bosch, J.A., \& Thøgersen-Ntoumani, C. (2011). Self-determination theory and diminished functioning: The role of interpersonal control and psychological need thwarting. Personality and Social Psychology Bulletin, 37, 1459-1473. https://doi.org/10.1177/0146167211413125

Biddle, S.J.H., Soos, I. and Chatzisarantıs, N. (1999). "Predicting physical activity intentions using a goal perspectives approach: a study of Hungarian youth", Scandinavian Journal of Medicine \& Science in Sports, 9: 353-357. https://doi.org/10.1111/j.16000838.1999.tb00256.x

Biddle, S.J.H. and Wang, C.K.J. (2003). Motivation and self-perception profiles and links with physical activity in adolescent girls. Journal of Adolescence, 26: 687-701. https://doi.org/10.1016/j.adolescence.2003.07.003

Boyd, M. (2019). Intrinsic Motivation among Skateboarders in Relation to Goal Orientation and Risk-Taking Behavior. Journal of Sport Behavior, 42(3), 305. 
Brunet, J., \& Sabiston, C. M. (2011). Exploring motivation for physical activity across the adult lifespan. Psychology of sport and exercise, 12(2), 99-105. https://doi.org/10.1016/j.psychsport.2010.09.006

Byers, T., Nestle, M., McTiernan, A., Doyle, C., Currie-Williams, A., Gansler, T., et al. (2002). American Cancer Society Guidelines on Nutrition and Physical Activity for Cancer $96 \mathrm{M}$. Hagger and N. Chatzisarantis Prevention: reducing the risk of cancer with healthy food choices and physical activity. CACancer Journal of Clinicians, 52, 92-119. https://doi.org/10.3322/canjclin.52.2.92

Brunet J. ve Sabiston C.M. (2011). Exploring motivation for physical activity across the adult lifespan. Psychol Sport Exerc.;12:99-105. https://doi.org/10.1016/j.psychsport.2010.09.006

Çankaya, Z.C. (2005). Öz-belirleme modeli: Özerklik desteği, ihtiyaç doyumu ve iyi olma, Gazi Üniversitesi, Eğitim Bilimleri Enstitüsü, Rehberlik ve Psikolojik Danışmanlık Anabilim Dali, Doktora Tezi.

Cengiz, C., Aşçı, F.H., İnce, M.L. (2010) "Egzersiz Davranışı Değişim Basamakları Anketi”: Geçerlik Ve Güvenirlik Çalışması Türkiye Klinikleri J Sports Sci, 2(1):32-37.

Chatzisarantis, N. L. D., Hagger, M. S., Biddle, S. J. H., Smith, B. and Wang, J. C. K. (2003). A meta-analysis of perceived locus of causality in exercise, sport, and physical education contexts. Journal of Sport and Exercise Psychology, 25: 284-306. https://doi.org/10.1123/jsep.25.3.284

Craig, C.L., Marshall, A.L., Sjostrom, M., Bauman, A.E. and Booth, M.L. (2003). International physical activity questionnaire: 12-country reliability and validity. Medicine and Science in Sports and Exercise, 35: 1381-1395, https://doi.org/10.1249/01.mss.0000078924.61453.fb

Daley, A. and Duda, J. L. (2006). Self-determination, stage of readiness to change for exercise, and frequency of physical activity in young people. European Journal of Sport Science, 6: 231243.https://doi.org/10.1080/17461390601012637

Deci E.L. ve Ryan, R.M. (1985). Intrinsic motivation and self-determination in human behavior, Plenum Press, New York.

Deci E.L. ve Ryan, R.M. (2000). The 'what' and 'why' of goal pursuits: Human needs and the selfdetermination of behavior, Psychological Inquiry 11: 227-268. https://doi.org/10.1207/s15327965pli1104_01

Duda, J. L., Chı, L., Newton, M.L., Wallıng, M.D., Catley, D. (1995). Task and ego orientation and intrinsic motivation in sport. International Journal of Sport Psychology, 26: 40-63.

Dweck, C. ve Leggett, E. (1988). A social-cognitive approach to motivation and personality. Psychological Review, 95(2), 256-273. https://doi.org/10.1037/0033-295x.95.2.256

Dyrlund, A.K. (2008). An Examination Of The Integrative Relationship Among The Factors Of Achievement Goal Theory And Self-Determination Theory: Addressing Existing Problems And Missing Links, Florida State University, College Of Education, Doctorate Thesis.

Edmunds, J., Ntoumanis, N. and Duda, J.L. (2006). A Test of Self-Determination Theory in the Exercise Domain. Journal of Applied Social Psychology, 36, 2240-2265. https://doi.org/10.1111/j.0021-9029.2006.00102.x

Edmunds, J.K., Ntoumanis, N., \& Duda, J.L. (2007). Perceived autonomy support and psychological need satisfaction in exercise. In M.S. Hagger \& N.L.D. Chatzisarantis (Eds.) Intrinsic motivation and self-determination in exercise and sport (pp. 3551). Champaign, IL: Human Kinetics. 
Erkoç, Y. ve Yardım, N. 2011. T.C. Sağlık Bakanlığı Temel Sağlık Hizmetleri Genel Müdürlüğü Türkiye'de Bulaşıcı Olmayan Hastalıklar ve Risk Faktörleri ile Mücadele Politikaları (1.Bask1). An1l Matbaas1, Ankara. https://doi.org/10.14527/9786053187752.11

Fritz, T., Wandell, P., Aberg, H., \& Engfeldt, P. (2006). Walking for exercise does three times per week influence risk factors in type 2 diabetes? Diabetes Research and Clinical Practice, 71, 21-27. https://doi.org/10.1016/j.diabres.2004.12.003

Gast, J., Madanat, H., \& Nielson, A. C. (2012). Are men more intuitive when it comes to eating and physical activity?. American journal of men's health, 6(2), 164-171. https://doi.org/10.1177/1557988311428090

Ersöz, G., Aşçı F. H., Altıparmak E. (2012). Egzersizde davranışsal düzenlemeler ölçeği-2: geçerlilik ve güvenilirlik çalışması (Reliability and validity of behavioral regulations in exercise questionnaire-2). Türkiye Klinikleri Journal Sports Science, 4(1): 22-31.

Ersöz, G., Müftüler, M., Lapa, T., Tümer, A. (2017). Reliability and validity of goal orientation in exercise measure (GOEM) - Turkish version. Cogent Education, 4:1283877. http://dx.doi.org/10.1080/2331186X.2017.1283877

Frederick, C. M. ve Ryan, R. M. (1993). Differences in motivation for sport and exercise and their relations with participation and mental health. Journal of Sport Behaviour, 16: 124-145.

Fox, K., Goudas, M., Biddle, S., Duda, J., Armstrong, N. (1994). Children's task and ego goal Achievement goal profiles 443 profiles in sport. British Journal of Educational Psychology, 64: 253-261. https://doi.org/10.1111/j.2044-8279.1994.tb01100.x

Goudas, M., Biddle, S., Fox, K. (1994). Perceived locus of causality, goal orientations, and perceived competence in school physical education classes, British Journal of Educational Psychology. Nov;64, (Pt 3): 453-463. https://doi.org/10.1111/j.2044-8279.1994.tb01116.x

Hagger M.S., Chatzisarantis N.L.D. (2007) Intrinsic motivation and self-determination in exercise and sport. Champaign, IL: Human Kinetics.

Hagger, M.S., Chatzisarantis, N.L.D. (2008). Self-determination theory and the psychology of exercise. International Review of Sport and Exercise Psychology, 1: 79-103. https://doi.org/10.1080/17509840701827437

Hagger, M.S., Chatzisarantis, N.L.D., and Harris, J. (2006). From psychological need satisfaction to intentional behavior: testing a motivational sequence in two behavioral contexts. Personality and Social Psychology Bulletin, 32, 131-138. https://doi.org/10.1177/0146167205279905

Haskell W.L., Lee I.M., Pate R.R., Powell K.E., Blair S.N., Franklin, B.A., ... Bauman (2007) A. Physical activity and public health: Updated recommendation for adults from the American College of Sports Medicine and the American Heart Association. Circulation;116:10811093. https://doi.org/10.1161/circulationaha.107.185649

Heuze, J. P., Eys, M., Dubuc, M., Bosselut, G., \& Couture, R. (2018). Cohesion, psychological needs, and intrinsic motivation in youth team sport contexts. International Journal of Sport Psychology, 49(1), 55-73.

Hooper, L., Summerbell, C.D., Higgins, J.P.T., Thompson, R.L., Capps, N.E., Smith, et al. (2001). Dietary fat intake and prevention of cardiovascular disease: systematic review. British Medical Journal, 322, 757-763. https://doi.org/10.1136/bmj.322.7289.757

Ingledew D.K., Markland D. (2008) The role of motives in exercise participation. Psychol Health, 23:807-828. https://doi.org/10.1080/08870440701405704 
Ingledew, D.K.I., Markland, D. and Medley, A. (1998). Exercise motives and Stages of Change. Journal of Health Psychology, 3: 477-489. https://doi.org/10.1177/135910539800300403

Kanamori S, Takamiya T, Inoue S. (2015). Group exercise for adults and elderly: determinants of participation in group exercise and its associations with health outcome. J Phys Fitness Sports Med.;4:315-320. https://doi.org/10.7600/jpfsm.4.315

Kamal, A. A., \& Zulkifli, A. F. (2019). The relationship between extrinsic motivation and physical activity level among students. Malaysian Journal of Movement, Health \& Exercise, 8(1).

Kazak, Z. (2018). Profiles of Basic Psychological Needs in Exercise Settings: An Examination of Differences in Contextual Motivation, Affect, and Achievement Goals. International journal of environmental research and public health, 15(12), 2871. https://doi.org/10.3390/ijerph15122871

Kazak Çetinkalp, Z., \& Lochbaum, M. (2018). Flourishing, affect, and relative autonomy in adult exercisers: A within-person basic psychological need fulfillment perspective. Sports, 6(2), 48. https://doi.org/10.3390/sports6020048

Kingston, K.M., Horrocks, C.S. ve Hanton, S. (2006). Do Multidimensional İntrinsic And Extrinsic Motivation Profiles Discriminate Between Athlete Scholarship Status And Gender?, European Journal Of Sport Science, March; 6(1): 53-63. https://doi.org/10.1080/17461390500440889

Kushner, R.F., Mechanick, J.I. 2015. "Lifestyle Medicine-An Emerging New Discipline". US Endocrinology. 11(1):36-40.

LI, W., LEE, A.M., SOLMON, M.A. (2005). Relationships among dispositional ability conceptions, intrinsic motivation, perceived competence, experience, persistence, and performance. Journal of Teaching in Physical Education, 24: 51-65. https://doi.org/10.1123/jtpe.24.1.51

Lonsdale, C., Hodge, K., \& Rose, E. A. (2008). The Behavioral Regulation in Sport Questionnaire (BRSQ): Instrument development and initial validity evidence. Journal of Sport \& Exercise Psychology, 30, 323-355. https://doi.org/10.1123/jsep.30.3.323

Losier, G. F. ve Vallerand, R. J. (1994). The temporal relationship between perceived competence and self-determined motivation. Journal of Social Psychology, 134: 793-801. https://doi.org/10.1080/00224545.1994.9923014

Losier, G. F., Bourque, P. E. ve Vallerand, R. J. (1993). A motivational model of leisure motivation in the elderly. Journal of Psychology, 127, 153-170. https://doi.org/10.1080/00223980.1993.9915551

Mack, D.E., Wilson, P.M., Oster, K.G., Kowalski, K.C., Crocker, P.R., \& Sylvester, B.D. (2011). Well-being in volleyball players: Examining the contributions of independent and balanced psychological need satisfaction. Psychology of Sport and Exercise, 12, 42 533-539. https://doi.org/10.1016/j.psychsport.2011.05.006

Mahony D. F., Madrigal R., \& Howard D. (2000), Using the psychological commitment to team (PCT) scale to segment sport consumers based on loyalty, Sport Marketing Quarterly, 9 (1), 15-25.

Mahony, D. F., Nakazawa, M, Funk, D. C., James, J. D., \& Gladden, J. M. (2002). Motivational factors influencing the behaviour of J. League spectators. Sports Management Review, 5(1), 1-24. https://doi.org/10.1016/s1441-3523(02)70059-4

Mahony, R., Blake, C., Matthews, J., Donnoghue, G. O., \& Cunningham, C. (2019). Physical activity levels and self-determined motivation among future healthcare professionals: Utility of the 
Behavioral Regulation in Exercise Questionnaire (BREQ-2). Physiotherapy theory and practice, 35(9), 884-890. https://doi.org/10.1080/09593985.2018.1457112

Markland, D. ve Tobin, V. (2004). A modification of the Behavioral Regulation in Exercise Questionnaire to include an assessment of amotivation. Journal of Sport and Exercise Psychology, 26: 191-196. https://doi.org/10.1123/jsep.26.2.191

Markland, D.(1999). Self-determination moderates the effects of perceived competence on intrinsic motivation in an exercise setting, Journal of Sport \& Exercise Psychology (JSEP), 21(4): 351-361. https://doi.org/10.1123/jsep.21.4.351

Mathes, S., McGivern, A. and Scneider, C. (1992). The influence of participation and gender on employees' motives for involvement in a corporate exercise program, Journal of Sport Management, 6: 1-14. https://doi.org/10.1123/jsm.6.1.1

McAuley, E., Wraith, S., Duncan, T.E. (1991). Self-efficacy, perception of success, and intnnsic motivation for exercise. Joumal of Applied Social Psychology. 21 9(2): 139-155. https://doi.org/10.1111/j.1559-1816.1991.tb00493.x

Moreno, J.A., Cervellô, E., Gonzâlez-Cutre, D. (2007). Analizando la motivación en el deporte: un estudio a través de la teoría de la autodeterminación. Apunt Psicol. No prelo. https://doi.org/10.11144/javeriana.upsy15-4.pmpc

Mullen, E., Markland, D., Ingledew, D.K. (1997). A graded conceptualization of self-determination in the regulation of exercise behavior: Development of a measure using confirmatory factor analysis. Personality and Individual Differences, 23: 745-752. https://doi.org/10.1016/s0191-8869(97)00107-4

Murcia, J.A.M., De San Român Blanco, M.L., Galındo, C.M., Villodre, N.A., Coll, D.G.C. (2007). Efeffects of the gender, the age and the practice frequency in the motivation and the enjoyment of the physical exercise. Fitness \& Performance Journal (Online Edition), 6(3).

Murcia, J.A.M., Coll, D.G.C. (2006). Predicción del disfrute en el ejercicio físico según la orientación disposicional y la motivación autodeterminada. Análisis y modificación de conducta, 32(146): 767-780. https://doi.org/10.3900/fpj.7.6.357.s

Nicholls J.G. (1984) Achievement motivation: Concepts of ability, subjective experience, task choice, and performance. Psychol Rev., 91:328-346. https://doi.org/10.1037/0033295x.91.3.328

Nicholls JG.(1989) The competitive ethos and democratic education. Cambridge, MA: Harvard University Press.

Ntoumanis, N., Biddle, S.J.H. (1999). Affect and achievement goals in physical activity: Ametaanalysis. Scandinavian Journal of Medicine and Science in Sports, 9: 315-332. https://doi.org/10.1111/j.1600-0838.1999.tb00253.x

Ntoumanis, N. (2005). A prospective study of participation in optional school physical education based on Self-determination Theory. Journal of Educational Psychology, 97, 444453. https://doi.org/10.1037/0022-0663.97.3.444

Ntoumani, C.T. ve Ntoumanis, N. (2006). The role of self-determined motivation in the understanding of exercise-related behaviours, cognitions and physical self-evaluations, Journal of Sports Sciences; 24(4): 393-404. https://doi.org/10.1080/02640410500131670

Ntoumanis, N., Thøgersen-Ntoumani, C., Quested, E., \& Hancox, J. (2017). The effects of training group exercise class instructors to adopt a motivationally adaptive communication style. 
Scandinavian journal of medicine \& science in sports, 27(9), 1026-1034. https://doi.org/10.1111/sms.12713

Özer, G. (2009). HİK Çerçevesinde İhtiyaç Doyumu, İçsel Güdülenme Ve Bağlanma Stillerinin Üniversite Öğrencilerinin Öznel İyi Oluşlarına Etkileri, Gazi Üniversitesi, Eğitim Bilimleri Enstitüsü, Eğitim Bilimleri ABD., Yüksek Lisans Tezi.

Öztürk, M. (2005). Üniversitede Eğitim-Öğretim Gören Ögrencilerde Uluslararası fiziksel Aktivite Anketinin Geçerliliği ve Güvenirliği ve Fiziksel Aktivite Düzeylerinin Belirlenmesi, Hacettepe Üniversitesi, Sağlık Bilimleri Enstitüsü, Fizik Tedavi Ve Rehabilitasyon Programı, Yüksek Lisans Tezi, Ankara.

Pelletier, L. G., Fortier, M. S., Vallerand, R. J., Tuson, K. M. and Brière, N. M. (1995). Toward a new measure of intrinsic motivation, extrinsic motivation, and amotivation in sports: The sport motivation scale (sms). Journal of Sport and Exercise Psychology, 17: 35-53. https://doi.org/10.1123/jsep.17.1.35

Petherick, C., Markland, D. (2008). The development of a goal orientation in exercise measure (GOEM). Measurement in Physical Education \& Exercise Science, 12(2): 55-71. https://doi.org/10.1080/10913670801903902

Pintrich, , P., ve Schunk, D. (1996). Motivation in education: Theory, research, and applications. New Jersey: Prentice- Hall.

Reınboth, M., Duda, J. (2006). Perceived motivacional climate, need satisfaction and indices of wellbeing in team sports: a longitudinal perspective. Psychol. Sport Exerc. 7: 269-286, https://doi.org/10.1016/j.psychsport.2005.06.002

Rodrigues, F., Bento, T., Cid, L., Neiva, H. P., Teixeira, D., Moutão, J., ... \& Monteiro, D. (2018). Can interpersonal behavior influence the persistence and adherence to physical exercise practice in adults? A systematic review. Frontiers in psychology, 9. https://doi.org/10.3389/fpsyg.2018.02141.

Rodrigues, F., Teixeira, D. S., Cid, L., Machado, S., \& Monteiro, D. (2019). The role of dark-side of motivation and intention to continue in exercise: A self-determination theory approach. Scandinavian journal of psychology. https://doi.org/10.1111/sjop.12582

Ryan, R. M., \& Deci, E. L. (2017). Self-determination theory: Basic psychological needs in motivation, development, and wellness. Guilford Publications. https://doi.org/10.7202/1041847ar

Ryan, R.R. and Deci, E.L. (2000). Self-Determination Theory and the Facilitation of Intrinsic Motivation, Social Development, and Well-Being. American Psychologist, 55: 68-78. https://doi.org/10.1037/0003-066x.55.1.68

Ryan, R.M., Frederick, C.M., Lepes, D., Rubio, N. and Sheldon, K.M. (1997). Intrinsic motivation and exercise adherence. International Journal of Sport Psychology, 28, 335-354.

Ryan, R.M., Frederıck, C.M., Lepes, D., Rubı, N., Sheldon, K.M. (1999). Intrinsic motivation and exercise adherence. International Journal of Sport Psychology, 28: 335-354.

Sabiston, C. M., Brunet, J., Kowalski, K. C., Wilson, P. M., Mack, D. E., \& Crocker, P. R. (2010). The role of body-related self-conscious emotions in motivating women's physical activity. Journal of Sport and Exercise Psychology, 32(4), 417-437. https://doi.org/10.1123/jsep.32.4.417 
Sebire, S. J., Standage, M., \& Vansteenkiste, M. (2009). Examining intrinsic versus extrinsic exercise goals: Cognitive, affective, and behavioral outcomes. Journal of Sport \& Exercise Psychology, 31, 189-210. https://doi.org/10.1123/jsep.31.2.189

Sibley, B. A., \& Bergman, S. M. (2018). What keeps athletes in the gym? Goals, psychological needs, and motivation of CrossFit ${ }^{\mathrm{TM}}$ participants. International Journal of Sport and Exercise Psychology, 16(5), 555-574. https://doi.org/10.1080/1612197x.2017.1280835

Smith, A. L., Ntoumanis, N., Duda, J. L., \& Vansteenkiste, M. (2011). Goal striving, coping, and well-being: A prospective investigation of the self-concordance model in sport. Journal of Sport \& Exercise Psychology, 33, 124-145. https://doi.org/10.1123/jsep.33.1.124

Standage, M., Duda, J.L., \& Ntoumanis, N. (2005). A test of Self-determination Theory in school physical education. British Journal of Educational Psychology, 75, 411-433. https://doi.org/10.1348/000709904x22359

Standage, M., Gillison, F.B., \& Treasure, D.C. (2007). Self-determination and motivation in physical education. In M.S. Hagger \& N.L.D. Chatzisarantis (Eds.) Intrinsic motivation and selfdetermination in exercise and sport (pp. 7185). Champaign, IL: Human Kinetics.

Standage, M., \& Ryan, R. M. (2019). Self-determination theory in sport and exercise. Handbook of sport psychology (4th ed., pp. 352-378). Hoboken, NJ: Wiley.

Stenling, A., Lindwall, M., \& Hassmén, P. (2015). Changes in perceived autonomy support, need satisfaction, motivation, and well-being in young elite athletes. Sport, Exercise, and Performance Psychology, 4(1), 50-61, https://doi.org/10.1037/spy0000027

Sylvester, B. D., Curran, T., Standage, M., Sabiston, C. M., \& Beauchamp, M. R. (2018). Predicting exercise motivation and exercise behavior: A moderated mediation model testing the interaction between perceived exercise variety and basic psychological need satisfaction. $\begin{array}{llll}\text { Psychology of } \text { Sport and } & \text { Exercise, 36, }\end{array}$ https://doi.org/10.1016/j.psychsport.2018.01.004

Tabachnick, B.G., Fidell, L.S. (2013). Using multivariate statistics (6th ed.). New Jersey: Pearso

T.C. Sağlık Bakanlığı. 2015. Sağlık İstatistikleri Yıllığı, https://dosyasb.saglik.gov.tr/Eklenti/23530,2015-yili29pdf.pdf?0 Son erişim tarihi: 21.03.2019

US Department of Health and Human Services (2008). Physical activity guidelines for Americans. Washington, DC: USDHHS.

Vallerand, R.J. (2001). Deci and Ryan's Self-Determination Theory: A View From the Hierarchical Model of İntrinsic and Extrinsic Motivation.

Vallerand, R.J. and Fortier, M.S. (1998). Measures of İntrinsic and extrinsic motivation in sport and physical activity: A review and critique. In J. Duda (Ed.). Advancements in sport and exercise psychology measurement, Morgan town.

Vallerand, R. J. ve Losier, G. F. (1999). An integrative analysis of intrinsic and extrinsic motivation in sport. Journal of Applied Sport Psychology, 11, 142-169. https://doi.org/10.1080/10413209908402956

Verner-Filion, J., Vallerand, R. J., Amiot, C. E., \& Mocanu, I. (2017). The two roads from passion to sport performance and psychological well-being: The mediating role of need satisfaction, deliberate practice, and achievement goals. Psychology of Sport and Exercise, 30, 19-29. https://doi.org/10.1016/j.psychsport.2017.01.009 
Vlachopoulos, S.P., Aşçı, F.H., Cıd, L., Ersöz, G., Gonzalez-Cutre, D., Moreno-Murcıa, J.A., Moutao, J. (2013). Cross-cultural invariance of the basic psychological needs in exercise scale and need satisfaction latent mean differences among Greek, Spanish, Portuguese and Turkish samples. Psychology of Sport and Exercise, 14(5): 622-631. https://doi.org/10.1016/j.psychsport.2013.03.002

Vlachopoulos, S.P., Michailidou, S. (2006). Development and initial validation of a measure of autonomy, competence, and relatedness in exercise: The Basic Psychological Needs in Exercise Scale. Measurement in physical education and exercise science, 10(3): 179-201. https://doi.org/10.1207/s15327841mpee1003_4

Wagner, L. A. (2009). Occupational stress and coping resources of K-12 probationary teachers. Yayımlanmamış Doktora tezi, The College of Education. University of Denver.

Wang, C.K.J., Biddle, S.J.H. (2001). Young people's motivational profiles in physical activity: A cluster analysis. Journal of Sport and Exercise Psychology, 23: 1-22. https://doi.org/10.1123/jsep.23.1.1

Wang, C. J., Koh, K. T., \& Chatzisarantis, N. (2009). An intra-individual analysis of players' perceived coaching behaviours, psychological needs, and achievement goals. International journal of sports science \& coaching, 4(2), 177-192. https://doi.org/10.1260/174795409788549472

Wilson, P. M., Rodgers, W. M. ve Fraser, S. N. (2002). Cross-validation of the revised motivation for physical activity measure in active women. Research Quarterly for Exercise \& Sport, 73(4), 471-478. https://doi.org/10.1080/02701367.2002.10609048

W1lson, P.M., Rodgers, W.M., Fraser, S.N., Murray, T.C. (2004). Relationships between exercise regulations and motivational consequences in university students. Research Quarterly for Exercise \& Sport, 75: 81-91. https://doi.org/10.1080/02701367.2004.10609136

Yeltepe, H. (2007). Spor ve Egzersiz Psikolojisi, Epsilon Yayıncılık, 1. Baskı.

Yli-Piipari, S., John Wang, C. K., Jaakkola, T., \& Liukkonen, J. (2012). Examining the growth trajectories of physical education students' motivation, enjoyment, and physical activity: A person-oriented approach. Journal of Applied Sport Psychology, 24(4), 401-417.

Zanatta, T., Rottensteiner, C., Konttinen, N., \& Lochbaum, M. (2018). Individual motivations, motivational climate, enjoyment, and physical competence perceptions in Finnish team sport athletes: a prospective and retrospective study. Sports. Basel: MDPI, 2018, 6(4), 165. https://doi.org/10.3390/sports6040165 